\title{
Antiproliferative and antimetabolic effects behind the anticancer property of fermented wheat germ extract
}

Christoph Otto ${ }^{1,5^{*}}$, Theresa Hahlbrock ${ }^{1,2+}$, Kilian Eich ${ }^{1,3+}$, Ferdi Karaaslan ${ }^{1,4+}$, Constantin Jürgens ${ }^{1}$, Christoph-Thomas Germer ${ }^{5}$, Armin Wiegering ${ }^{5,6}$ and Ulrike Kämmerer ${ }^{7}$

\begin{abstract}
Background: Fermented wheat germ extract (FWGE) sold under the trade name Avemar exhibits anticancer activity in vitro and in vivo. Its mechanisms of action are divided into antiproliferative and antimetabolic effects. Its influcence on cancer cell metabolism needs further investigation. One objective of this study, therefore, was to further elucidate the antimetabolic action of FWGE. The anticancer compound 2,6-dimethoxy-1,4-benzoquinone (DMBQ) is the major bioactive compound in FWGE and is probably responsible for its anticancer activity. The second objective of this study was to compare the antiproliferative properties in vitro of FWGE and the DMBQ compound.
\end{abstract}

Methods: The $I_{50}$ values of FWGE were determined for nine human cancer cell lines after $24 \mathrm{~h}$ of culture. The DMBQ compound was used at a concentration of $24 \mu \mathrm{mol} / \mathrm{l}$, which is equal to the molar concentration of DMBQ in FWGE. Cell viability, cell cycle, cellular redox state, glucose consumption, lactic acid production, cellular ATP levels, and the $\mathrm{NADH} / \mathrm{NAD}^{+}$ratio were measured.

Results: The mean $I C_{50}$ value of FWGE for the nine human cancer cell lines tested was $10 \mathrm{mg} / \mathrm{ml}$. Both FWGE $(10 \mathrm{mg} / \mathrm{ml})$ and the DMBQ compound $(24 \mu \mathrm{mol} / \mathrm{l})$ induced massive cell damage within $24 \mathrm{~h}$ after starting treatment, with changes in the cellular redox state secondary to formation of intracellular reactive oxygen species. Unlike the DMBQ compound, which was only cytotoxic, FWGE exhibited cytostatic and growth delay effects in addition to cytotoxicity. Both cytostatic and growth delay effects were linked to impaired glucose utilization which influenced the cell cycle, cellular ATP levels, and the NADH/NAD ${ }^{+}$ratio. The growth delay effect in response to FWGE treatment led to induction of autophagy.

Conclusions: FWGE and the DMBQ compound both induced oxidative stress-promoted cytotoxicity. In addition, FWGE exhibited cytostatic and growth delay effects associated with impaired glucose utilization which led to autophagy, a possible previously unknown mechanism behind the influence of FWGE on cancer cell metabolism.

Keywords: FWGE, Benzoquinone, Cancer cells, Reactive oxygen species, Autophagy, Cytotoxicity, Cytostatic

\footnotetext{
* Correspondence: Otto_c@ukw.de

${ }^{\dagger}$ Equal contributors

${ }^{1}$ Experimental Surgery, Department of General, Visceral, Vascular, and

Pediatric Surgery, University Hospital of Würzburg, Oberdürrbacher Str. 6,

D-97080 Würzburg, Germany

${ }^{5}$ Department of General, Visceral, Vascular and Pediatric Surgery, University

Hospital of Würzburg, Oberdürrbacher Str. 6, D-97080 Würzburg, Germany

Full list of author information is available at the end of the article
} 


\section{Background}

Fermented wheat germ extract (FWGE) with the trade name Avemar is a licensed medical nutriment for cancer patients [1]. The anticarcinogenic potential of FWGE has been demonstrated in vitro and in vivo [2,3] and confirmed in two clinical trials: an open-label cohort trial with 170 colorectal cancer patients [4], and a randomized phase II trial with 46 stage III melanoma patients [5] receiving continuous supplementation of FWGE along with standard treatment. In both trials, FWGE was found to be beneficial in terms of overall and progression-free survival compared to standard therapy alone.

FWGE is produced as an aqueous extract, which contains the antitumor compounds 2,6-dimethoxy-1,4benzoquinone (DMBQ) and 2-methoxy-benzoquinone in a concentration of approximately $400 \mu \mathrm{g} / \mathrm{g}(0.04 \%)$ crude extract [2]. Quinones are cyclic organic compounds containing two carbonyl groups $(\mathrm{C}=\mathrm{O})$ linked to the cyclic structure of a conjugated system. Some clinical anti-cancer compounds, e.g. Mitomycin C, Mitoxantran, Doxorubicin, and Daunorubicin are quinone derivatives [6, 7]. In the 1970s, Bachur et al. described intracellular activation of benzoquinones to free radicals that irreversibly damage biomolecules, e.g. nucleic acids and proteins, but the benzoquinone-mediated production of reactive oxygen species represented the primary source of cell damage [8]. In the mid-1980s, the team of Nobel Prize winner Albert Szent-Györgyi examined the electrochemical and cytotoxic properties of benzoquinones: they injected DMBQ into the peritoneal cavity of mice harboring Ehrlich ascites tumor cells and found a complete elimination of tumor cells [9].

Reactive oxygen species (ROS) represent a broad range of chemically distinct reactive species of radicals with a single unpaired electron, including the superoxide anion radical $\left(\mathrm{O}_{2}^{-}\right)$and the hydroxyl radical $\left(\mathrm{OH}^{-}\right)$, as well as non-radical ROS such as hydrogen peroxide $\left(\mathrm{H}_{2} \mathrm{O}_{2}\right)$. A marked increase in intracellular ROS can cause oxidative stress with irreversible cell damage [10]. Mammalian cells contain different types of intracellular non-enzymatic and enzymatic antioxidants, e.g. the tripeptide glutathione [11], catalase, and DT-diaphorase that protect them from unwanted oxidative damage [12]. DT-diaphorase plays an important role in protecting cells against endogenous and exogenous quinones [13].

FWGE influences the metabolism of cancer cells [14] which utilize glucose in a way distinct from normal cells [15]. A better understanding of how FWGE influences cancer cell metabolism could improve our understanding of its anticancer activity. The first objective of the present study was to further elucidate the antimetabolic properties of FWGE in cancer cells. The anticancer compound DMBQ appears to be the bioactive molecule in FWGE responsible for its antiproliferative and antimetabolic properties [2]. This assumption has not yet been confirmed experimentally. The second objective of this study, therefore, was to compare the antiproliferative properties of FWGE and the DMBQ compound (at a concentration equal to that in FWGE) in nine human cancer cell lines.

\section{Methods}

\section{Cell lines}

Human malignant cell lines (Table 1) were routinely cultured in RPMI 1640 medium at $37{ }^{\circ} \mathrm{C}$ and $5 \%$ $\mathrm{CO}_{2}$ supplemented with $10 \%(\mathrm{v} / \mathrm{v})$ heat-inactivated fetal calf serum (FCS), $100 \mathrm{U} / \mathrm{ml}$ penicillin, $100 \mu \mathrm{g} / \mathrm{ml}$ streptomycin, $2 \mathrm{mmol} / \mathrm{l}$ glutamine, $50 \mathrm{mmol} / \mathrm{l}$ mercaptoethanol, and $1 \%$ non-essential amino acids in final concentrations (Invitrogen Life Technologies $\mathrm{GmbH}$, Karlsruhe, Germany).

\section{Drugs and chemicals}

FWGE powder from Biropharma, Hungary, was used. For each experiment, a fresh stock solution containing $100 \mathrm{mg} / \mathrm{ml}$ FWGE was prepared with RPMI 1640 medium and passed through a $0.2 \mu \mathrm{m}$ filter. FWG contains benzoquinones in a concentration of approx. $400 \mu \mathrm{g} / \mathrm{g}(0.04 \%)$ crude extract as described previously [2]. The antitumor compound DMBQ (molecular weight: $168 \mathrm{~g} / \mathrm{mol}$ ) at $97 \%$ purity (Sigma-Aldrich, Germany) was used in the same molar concentration of $24 \mu \mathrm{mol} / \mathrm{l}$ as described for FWGE (Avemar) [2]. The DMBQ concentration for $10 \mathrm{mg} / \mathrm{ml} \mathrm{FWGE}(=24 \mu \mathrm{mol} / \mathrm{l})$ was calculated as follows: [10 mg/ml (10 g/l $)$ x $0.04 \%$ \%/

Table $1 I_{50}$ values of FWGE for different human cancer cell lines. $\mathrm{IC}_{50}$ values in $\mathrm{mg} / \mathrm{ml}$ are shown as mean \pm standard deviation (SD) of three independent experiments, each performed in triplicate and calculated as described [21]. Cancer cells were treated for $24 \mathrm{~h}$ with different concentrations of FWGE (0.1, 1.0, 10, $50 \mathrm{mg} / \mathrm{ml}$ ) in medium with $10 \%$ (v/v) fetal calf serum (FCS) and cell viability was determined by crystal violet (CV)

\begin{tabular}{llcc}
\hline Cell line & Tissue & Mean & SD \\
\hline MDA-MB-468 $^{\text {a }}$ & Adenocarcinoma of the breast [33] & 3.8 & 1.77 \\
ASPC-1 ${ }^{\text {b }}$ & Adenocarcinoma of the pancreas [34] & 4.0 & 0.37 \\
BxPC-3 $^{\text {b }}$ & Adenocarcinoma of the pancreas [34] & 4.4 & 0.66 \\
MDA-MB-231 $^{\text {a }}$ & Adenocarcinoma of the breast [33] & 5.5 & 0.08 \\
23132/87 & Adenocarcinoma of the stomach [35] & 7.9 & 2.05 \\
HT-29 $^{\text {a }}$ & Adenocarcinoma of the colon [36] & 10.9 & 6.36 \\
BT-20 $^{\text {c }}$ & Adenocarcinoma of the breast [37] & 13.3 & 7.41 \\
HRT-18 $^{\text {b }}$ & Adenocarcinoma of the colon [38] & 15.8 & 7.83 \\
MCF-7 $^{\text {a }}$ & Invasive breast ductal carcinoma [37] & 19.3 & 17.66
\end{tabular}

Cell sources: ${ }^{a} \mathrm{CLS}$ : Cell Lines Services GmbH, Eppelheim, Germany (www.clsgmbh.de); ${ }^{\mathrm{b} I O P}$ : Institute of Pathology, University of Würzburg, Germany. 'DOG: Department of Obstetrics and Gynaecology, University of Würzburg Hospital, Germany 
$168 \mathrm{~g} / \mathrm{mol}$. For each experiment, a fresh stock solution of $0.1 \mathrm{mg} / \mathrm{ml}(595 \mu \mathrm{mol} / \mathrm{l})$ DMBQ was set-up in RPMI 1640 medium at $37{ }^{\circ} \mathrm{C}$ for $10 \mathrm{~min}$ to improve solubility. After passing the stock solution through a $0.2 \mu \mathrm{m}$ filter, no DMBQ sediment was observed. A fresh and sterile stock solution of $2.4 \mathrm{mmol} / \mathrm{l}$ ascorbic acid in RPMI 1640 medium was prepared as described [16].

\section{Measurement of FWGE effects on cell growth}

Cells $\left(1.5 \times 10^{4}\right)$ were seeded in $200 \mu$ l culture medium per well into 96-well flat-bottom tissue plates (Greiner bio-one, Germany). The next day, cells were incubated for $24 \mathrm{~h}$ with fresh culture medium containing the final concentrations of $0.1,1.0,10,50 \mathrm{mg} / \mathrm{ml}$ FWGE according to published data [17-19]. The tissue plates were cultured at $37{ }^{\circ} \mathrm{C}$ in a humidified atmosphere of $5 \%$ $\mathrm{CO}_{2}$ in air and cellular viability was determined by crystal violet $(\mathrm{CV})$ staining as described previously [20]. The absorbance (optical density, OD) was measured with a microplate reader (MRX, Dynatech Laboratories) at a wave length of $570 \mathrm{~nm}$ which is directly proportional to the number of viable cells. Dose-response curves were used to calculate $\mathrm{IC}_{50}$ values as described

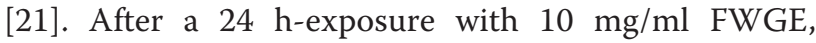
the following three antiproliferative effects (which influence the number of viable cells) were observed: cytotoxic, cytostatic, and growth delay. By definition, a cytotoxic effect is a reduction in initial viable cell count $>15 \%$, a cytostatic effect a change in initial viable cell count $\pm 15 \%$, and delayed growth effect an increase in initial viable cell count $>15 \%$.

Determination of cellular ATP content and NADH/NAD ${ }^{+}$ratio Cellular ATP content was determined with the Colorimetric/Fluorometric Assay Kit (K354-100) from BioVision, USA according to the manufacturer's instructions. ATP content was given in $\mathrm{pg} / 10^{6}$ cells for $24 \mathrm{~h}$. The $\mathrm{NADH} / \mathrm{NAD}^{+}$ratio, determined with the quantitation colorimetric kit (K337-100) from BioVision, was given for $10^{4}$ cells.

\section{Measuring cellular redox state}

The OxiSelect ${ }^{\mathrm{Tm}}$ Intracellular ROS Assay Kit (Gell Biolabs, USA; STA-342) is a cell-based assay for measuring the activity of hydroxyl, peroxyl, and other reactive oxygen species within a cell. The assay employs the redox-sensitive fluorogenic dye DCFH-DA, which diffuses into cells and is deacetylcated by cellular esterases into the non-fluorescent DCFH. In the presence of ROS, DCFH is rapidly oxidized to highly fluorescent DCF. Fluorescence was quantified $12 \mathrm{~h}$ and $24 \mathrm{~h}$ after incubation with FWGE and DMBQ on a standard fluorescence plate reader at $480 / 530 \mathrm{~nm}$. Results are presented as relative fluorescence units normalized for $10^{4}$ cells.
Glucose consumption and lactic acid production

Cells $\left(1.5 \times 10^{4}\right)$ were seeded in $200 \mu$ l culture medium per well into 96-well flat-bottom tissue plates (Greiner bio-one). After $24 \mathrm{~h}, 48 \mathrm{~h}$, and $72 \mathrm{~h}$ of culture, cell-free supernatant was analyzed for glucose consumption and lactic acid production by the central laboratory of the University Hospital of Würzburg using the Cobas 8000 modular analyzer series (Roche Diagnostics, Germany). Glucose consumption was calculated from the difference between glucose concentration in cellfree control medium and glucose concentration remaining in the supernatant of cell cultures after incubation. Lactic acid production was calculated from the difference between lactic acid concentrations in the supernatant of cell cultures before and after incubation. Results were correlated to the cell count and displayed as consumption/production per $10^{4}$ cells.

\section{Western blotting}

Western blotting was performed as described earlier $[22,23]$. In brief, $1 \times 10^{6}$ cells each were lysed in precooled RIPA buffer (Pierce, USA) containing phosphatase and proteinase inhibitors and $2.5 \mathrm{mmol} / \mathrm{l}$ dithiothreitol (Sigma-Aldrich). Equal amounts of proteins $(30 \mu \mathrm{g})$ were loaded on a $10 \%$ polyacrylamide gel (SDS-PAGE), electrophoresed, and then blotted by semi-dry transfer onto a nitrocellulose membrane (Schleicher \& Schuell, Germany). After a blocking step with $5 \%$ non-fat milk (Merck, Germany), membranes were incubated with either a rabbit anti-DT diaphorase primary antibody (NQ01, N5288, Sigma-Aldrich; diluted 1:2,000) or a rabbit antiLC3-I/-II primary antibody (AHP2167T; AbD Serotec $\mathrm{GmbH}$, Germany; diluted 1:1,000). After washing with phosphate buffered saline (PBS), membranes were incubated with a horseradish peroxidaseconjugated goat antirabbit secondary antibody (KPL, USA; diluted 1:10,000) for $60 \mathrm{~min}$ at room temperature. A monoclonal mouse anti- $\beta$ actin primary antibody (Abcam, UK; diluted 1:10,000) was used as loading control and visualized with the goat antimouse secondary antibody (KPL, diluted 1: 10,000). Immunoblots were visualized by enhanced chemiluminescence western blotting substrate (Pierce, Thermo Scientific, USA) with subsequent exposure on an X-ray film (Fuji Super RX medical X-ray films; Fuji, Germany) for $30 \mathrm{~s}$.

\section{Cell cycle analysis}

For cell cycle analysis, $1 \times 10^{6}$ cells were fixed in suspension with $70 \%$ ice-cold ethanol $\left(-20{ }^{\circ} \mathrm{C}\right)$ and incubated for $2 \mathrm{~h}$ at $4{ }^{\circ} \mathrm{C}$. Subsequently, ice-cold PBS was added and the cells were pelleted at $250 \mathrm{xg}$ for $6 \mathrm{~min}$ at $4{ }^{\circ} \mathrm{C}$. Cell pellets were resuspended with PBS. RNase (lnvitrogen $\mathrm{GmbH}$, Germnay) was added for a final concentration of $50 \mu \mathrm{g} / \mathrm{ml}$ and incubated at $37{ }^{\circ} \mathrm{C}$ for $30 \mathrm{~min}$ in the dark. Then propidium iodide (Sigma-Aldrich; stock solution: $1 \mathrm{mg} / \mathrm{ml}$, final concentration: $50 \mu \mathrm{g} / \mathrm{ml}$ ) was 
added. After $5 \mathrm{~min}$ of incubation, the cells were measured for their DNA amount with a FACScan (Becton Dickinson, Germany). Data (10,000 events per acquisition) were recorded with BD CellQuest ${ }^{\mathrm{TM}}$ Pro software (Version 5.1.1) and data were analyzed with WinMDI software (Version 2.9).

\section{Statistical analysis}

The experiments were performed at least three times with triplicate samples. The means were compared using analysis of variance (ANOVA) plus Bonferroni's $t$-test. A $P$-value of $<0.05$ was considered to indicate a statistically significant result.

\section{Results}

\section{Antiproliferative properties of FWGE}

The mean $\mathrm{IC}_{50}$ value of FWGE determined for nine cancer cell lines tested after $24 \mathrm{~h}$ of culture was $10 \mathrm{mg} / \mathrm{ml}$ (range from 3.8 to $19.3 \mathrm{mg} / \mathrm{ml}$ ) (Table 1 ). The pancreatic cancer cell lines BxPC-3 and ASPC-1 and breast cancer cell lines MDA-MB-468 and MDA-MB-231 were extremely sensitive to $\mathrm{FWGE}$ with $\mathrm{IC}_{50}$ values ranging from $3.8 \pm 1.77$ to $5.5 \pm 0.08 \mathrm{mg} / \mathrm{ml}$. FWGE had less effect on the viability of MCF-7 cells $(19.3 \pm 17.66 \mathrm{mg} / \mathrm{ml})$, which were the most insensitive cells to FWGE tested in this study. The calculation of Kendall's tau-b rank correlation coefficient displayed a strong correlation between the $\mathrm{EC}_{50}$ values of the cell lines tested and the antiproliferative properties of FWGE $(r=0.545, P<0.05)$. In cell lines with $\mathrm{IC}_{50}<6.0 \mathrm{mg} / \mathrm{ml}$, FWGE usually triggered cytotoxic effects, in cell lines with $\mathrm{IC}_{50}>6.0 \mathrm{mg} / \mathrm{ml}$, FWGE usually triggered cytostatic effects.

Characterization of the antiproliferative effect of the mean $\mathrm{IC}_{50}$ value of $10 \mathrm{mg} / \mathrm{ml}$ FWGE after $24 \mathrm{~h}$ treatment of the nine cancer cell lines revealed a cytotoxic effect in four cell lines (ASPC-1, BxPC3, MDA-MB-231, MDA-MB-468), a cytostatic effect in four cell lines (23132/87, BT-20, HT-29, MCF-7) and a growth delay effect in HRT-18 cells (Additional file 1: Figure S1 and Fig. 1a). FWGE at a concentration of $1 \mathrm{mg} / \mathrm{ml}$ had no effect on cell viability and $50 \mathrm{mg} / \mathrm{ml}$ was cytotoxic for all nine cell lines after a $24 \mathrm{~h}$ treatment (not shown). A concentration of $10 \mathrm{mg} / \mathrm{ml}$ FWGE has been reported to induce biological responses in normal peripheral blood lymphocytes in vitro [18]. Therefore, we did not use concentrations $>10 \mathrm{mg} / \mathrm{ml}$ FWGE to analyze its antiproliferative effects.

\section{Antiproliferative properties of FWGE and DMBQ}

One cell line each was selected to investigate the three antiproliferative properties of FWGE: BxPC-3 cells (cytotoxic effect), 23132/87 cells (cytostatic effect) and HRT18 cells (growth delay effect). The DMBQ compound was used in a concentration of $24 \mu \mathrm{mol} / \mathrm{l}$, which is equal to its concentration in FWGE. At this concentration, the DMBQ compound induced strong cytotoxicity in all nine cancer cell lines tested after $24 \mathrm{~h}$ of treatment. Representative results for the three cell lines BxPC-3, 23132/87 and HRT-18 are shown in Fig. 1a, results for other cell lines in the Additional file 1: Figure S1. BxPC3 cells reacted very sensitively to treatment with FWGE and DMBQ. The cytotoxicity induced by DMBQmediated ROS is well known [8, 9]. We found that the massive cell damage induced by the DMBQ compound and FWGE was linked to aberrant levels of intracellular DCF fluorescence. This shift in the cellular redox state was caused by intracellular ROS (Fig. 1b) and was confirmed by experiments with exogenous glutathione (Additional file 2: Figure S2). Exogenous glutathione (GSH) protected BxPC-3 cells against DMBQ compound/ FWGE-induced cell damage, confirming the oxidativetype cytotoxicity of DMBQ and FWGE. The strong cytotoxic effect of FWGE and the DMBQ compound in BxPC-3 cells was linked to a loss of the enzyme DTdiaphorase (Additional file 3: Figure S3) which protects cells against benzoquinone-induced oxidative stress. The FWGE-induced cytostatic and growth delay effects in 23132/87 and HRT-18 cells were linked to moderate ROS levels (Fig. 1b). In contrast to its cytotoxic effect, FWGE's cytostatic and growth delay effects were not influenced by GSH (Additional file 2: Figure S2).

\section{Metabolic effects of FWGE}

The cytostatic and growth delay effects of FWGE in 23132/87 and HRT-18 cells indicate that it influences cell metabolism and function. We found that the FWGE-induced cytostatic effect in 23132/87 cells is based on cell cycle arrest (Additional file 4: Figure S4). In addition, we found that the FWGE-induced cytostatic effect in 23132/87 cells was linked to impaired glucose consumption and significantly reduced production of lactic acid $(P<0.01$, Fig. 2a,c). In HRT-18 cells, the growth delay effect of FWGE was also linked to impaired glucose consumption and the cells produced less lactic acid (Fig. 2b,d). However, in comparison to untreated HRT-18 cells, it was obvious that FWGE-treated HRT-18 cells produced more lactic acid than expected based on overall glucose consumption after 48 and $72 \mathrm{~h}$ of culture (Fig. 2b,d). At 72 h of culture, FWGE-treated HRT-18 cells consumed four-fold less glucose than FWGE-untreated cells but produced the same levels of lactic acid, indicating that HRT-18 cells are able to shift their metabolism to other energy sources than glucose linked with production of lactic acid, e.g. glutamine via glutaminolysis.

Impaired glucose consumption can affect cellular energy sources. We therefore measured cellular ATP and NADH levels in 23132/87 and HRT-18 cells. FWGE- 
A

BxPC-3

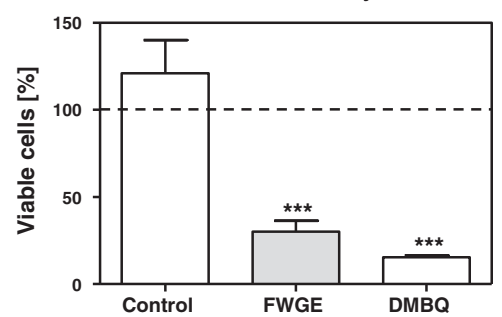

23132/87

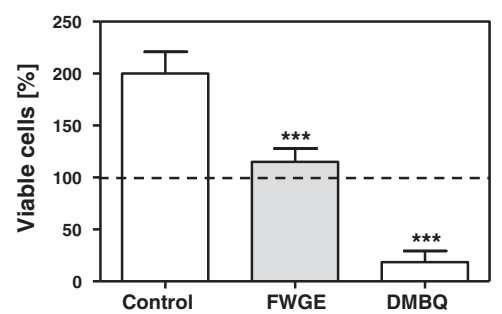

HRT-18

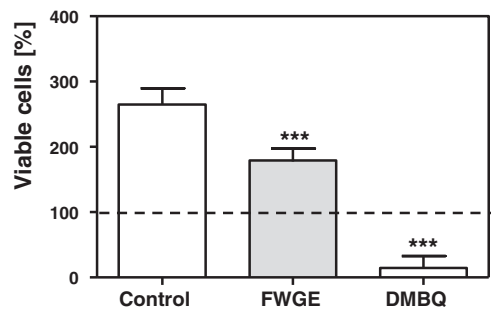

B
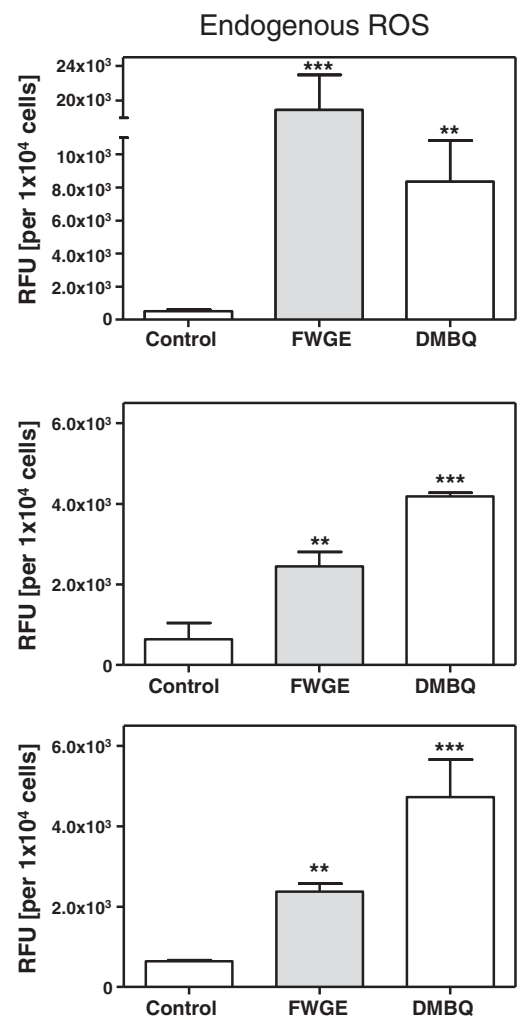

Fig. 1 Antiproliferative properties of FWGE and DMBQ. The effects of FWGE (mean IC $\left.C_{50}: 10 \mathrm{mg} / \mathrm{ml}\right)$ and DMBQ $(24 \mu \mathrm{mol} / \mathrm{l}$; equal to the DMBQ concentration in FWGE) on cancer cell viability (a). Intracellular DCF fluorescence signals indicating intracellular ROS formation after $12 \mathrm{~h}$ (BxPC-3 cells) and $24 \mathrm{~h}$ (23132/87 and HRT-18 cells) of culture (b). The dashed line indicates the relative initial cell count at the start of treatment. For this, the seeded cells were stained with crystal violet directly after their adherence and the absorbance was normalized to $100 \%$. By definition, a cytotoxic effect was a reduction in initial viable cell count $>15 \%$, a cytostatic effect a change in initial cell count of $\pm 15 \%$, and a delayed growth effect an increase in the initial cell count $>15 \%$. Ascorbic acid (2.4 mmol/l) was used to activate DMBQ [16]. Ascorbic acid had no influence on cancer cell viability or FWGE (not shown). Results are shown as mean \pm standard deviation and representative for at least three independent experiments performed in triplicate. ${ }^{* *} P<0.01,{ }^{* * *} P<0.001$ in comparison to untreated control cells. RFU, relative fluorescence units

treated $23132 / 87$ cells exhibited a $66 \%$ depletion in cellular ATP and a $60 \%$ decrease in the $\mathrm{NADH} / \mathrm{NAD}^{+}$ratio (Fig. 2e). In HRT-18 cells, FWGE also decreased the $\mathrm{NADH} / \mathrm{NAD}^{+}$ratio by $64 \%$ (Fig. 2f) with unchanged cellular ATP content. The decrease in the NADH/NAD ${ }^{+}$ratio, reflecting an increase in the amount of (non-reduced) $\mathrm{NAD}^{+}$, indicates that FWGE influenced the reduction of the $\mathrm{NAD}^{+}$pool in these cells.

\section{FWGE-induced autophagy}

The unchanged ATP content in FWGE-treated HRT-18 cells (Fig. 2f) was linked to growth delay (Fig. 1) with prolonged cell survival in continuous culture with FWGE (Fig. 3). Microscopic analysis of FWGE-treated HRT-18 cells demonstrated the formation of intracellular vacuoles, first observed $24 \mathrm{~h}$ after starting incubation, which increased in size with increasing incubation time (Fig. 4). To determine whether the FWGE-induced formation of intracellular vacuoles was a characteristic sign of autophagy, a pro-survival self-degradation process under metabolic stress, we analyzed the cells for the presence of the autophagy marker LC3-II. With an anti-LC3 antibody, we confirmed the presence of LC3-II exclusively in FWGE-treated HRT-18 cells (Fig. 4). This indicates an accumulation of HRT-18 cells within the cell population demonstrating autophagic activity during incubation with FWGE.

\section{Discussion}

ln this study we analyzed the antiproliferative and antimetabolic effects of fermented wheat germ (FWGE) sold under the trade name Avemar. Because FWGE contains the anticancer compound $\mathrm{DMBQ}$, which is thought to be responsible for the antiproliferative and antimetabolic properties of FWGE [2], we investigated whether FWGE and DMBQ exhibit similar antiproliferative effects. For 
A

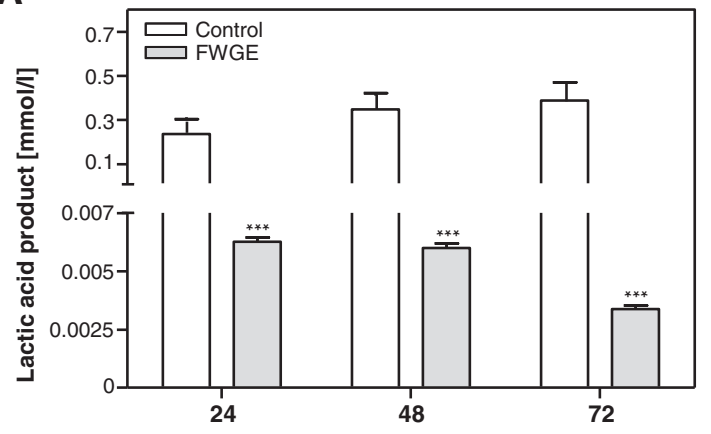

C

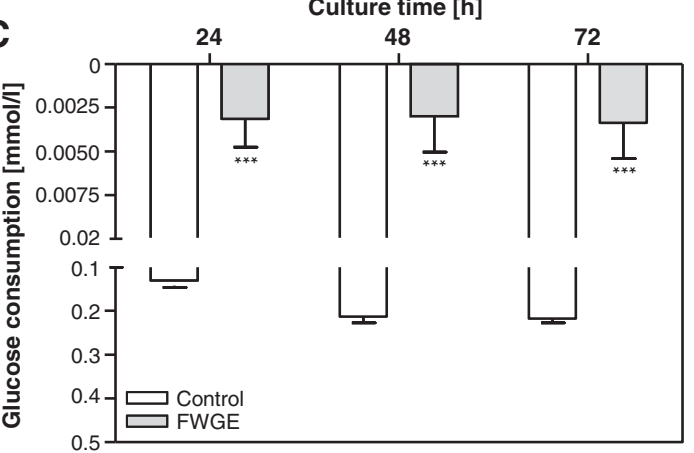

E
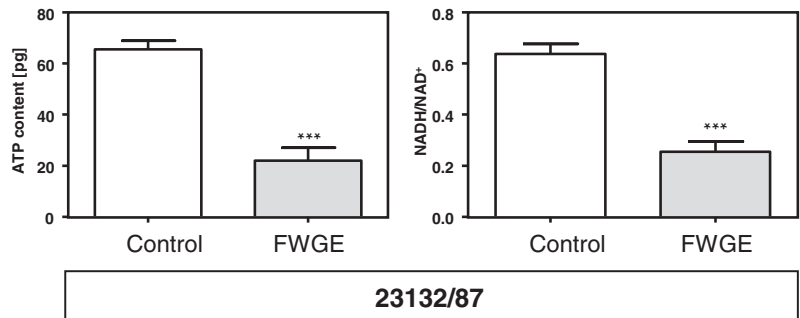

B

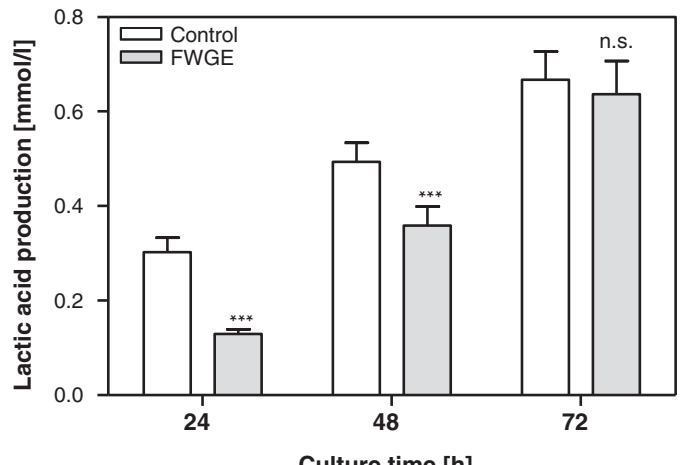

D

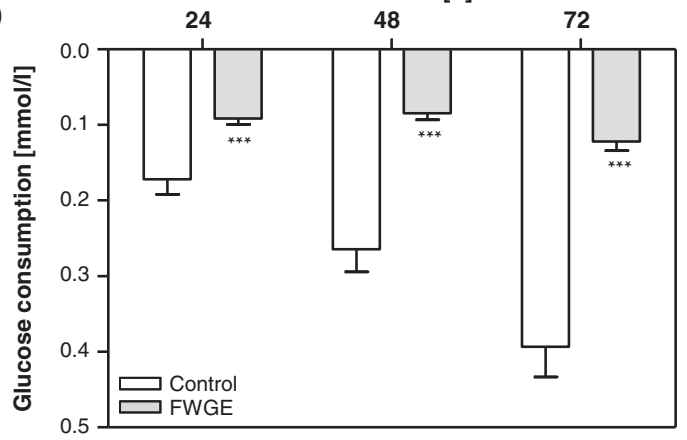

$\mathbf{F}$

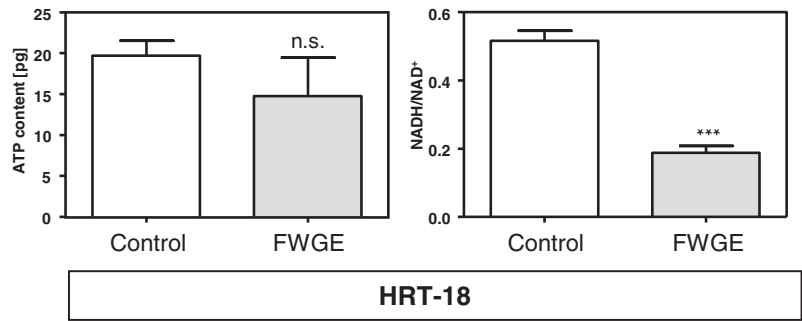

Fig. 2 FWGE-influenced cancer cell metabolism. Lactic acid production ( $\mathrm{mmol} / \mathrm{l}$ for $10^{4}$ cells) and glucose consumption (mmol// for $10^{4} \mathrm{cells}$ ) by 23132/87 cells $(\mathbf{a}, \mathbf{c})$ and HRT-18 cells $(\mathbf{b}, \mathbf{d})$ with and without FWGE treatment for the incubation times indicated. Cellular ATP content ( $\mathrm{pg} / 10^{6}$ cells) and the NADH/NAD ratio in 23132/87 cells (e) and HRT-18 cells ( $\mathbf{f}$ ) with and without FWGE treatment after $24 \mathrm{~h}$ of culture. Results are shown as mean \pm standard deviation for three independent experiments. ${ }^{* * *} P<0.001$ to FWGE-untreated cells

this purpose, the DMBQ compound was used in a molar concentration of $24 \mu \mathrm{mol} / \mathrm{l}$ equal to its concentration in FWGE $[2,3]$. FWGE and DMBQ were tested on nine human cancer cell lines derived from different cancer types (Table 1). In addition, the effect of Avemar was also tested on normal human dermal fibroblasts (PromoCell, Germany) with an $\mathrm{IC}_{50}$ value of $35.5 \pm 20.5 \mathrm{mg} / \mathrm{ml}$ (not shown). $24 \mu \mathrm{mol} / \mathrm{l}$ of the DMBQ compound was found to be cytotoxic for all cancer cell lines tested within 24 h (Additional file 1: Figure S1), whereas $10 \mathrm{mg} / \mathrm{ml}$ FWGE (mean $\mathrm{IC}_{50}$ value) exhibited additional cytostatic and growth delay effects. In this context, it is worth mentioning that $10 \mathrm{mg} / \mathrm{ml} \mathrm{FWGE} \mathrm{in} \mathrm{con-}$ tinuous culture with cancer cells was cytotoxic (Fig. 3), as was $50 \mathrm{mg} / \mathrm{ml} \mathrm{FWGE} \mathrm{for} 24 \mathrm{~h}$ (not shown). The treatment of cells with $10 \mathrm{mg} / \mathrm{ml}$ FWGE for $24 \mathrm{~h}$ allowed us to investigate the antimetabolic mechanisms of FWGE in detail.

DMBQ-mediated ROS-induced cytotoxicity is well known $[8,9,24,25]$. We found that DMBQ-induced cell damage was linked to increased intracellular DCF fluorescence. A comparable increase in DCF fluorescence was also found in BXPC-3 cells incubated with FWGE and indicates the production of intracellular ROS. Detection of ROS based on DCF fluorescence is the most widely used assay but various caveats apply [26]. Our present findings provide further evidence for DMBQ/ FWGE-induced ROS production, showing that exogenous glutathione $(\mathrm{GSH})$ protected BxPC3 cells against DMBQ/FWGE-induced cell damage. Cellular glutathione levels are maintained by de novo synthesis, reduction of glutathione disulfide, and glutathione uptake 


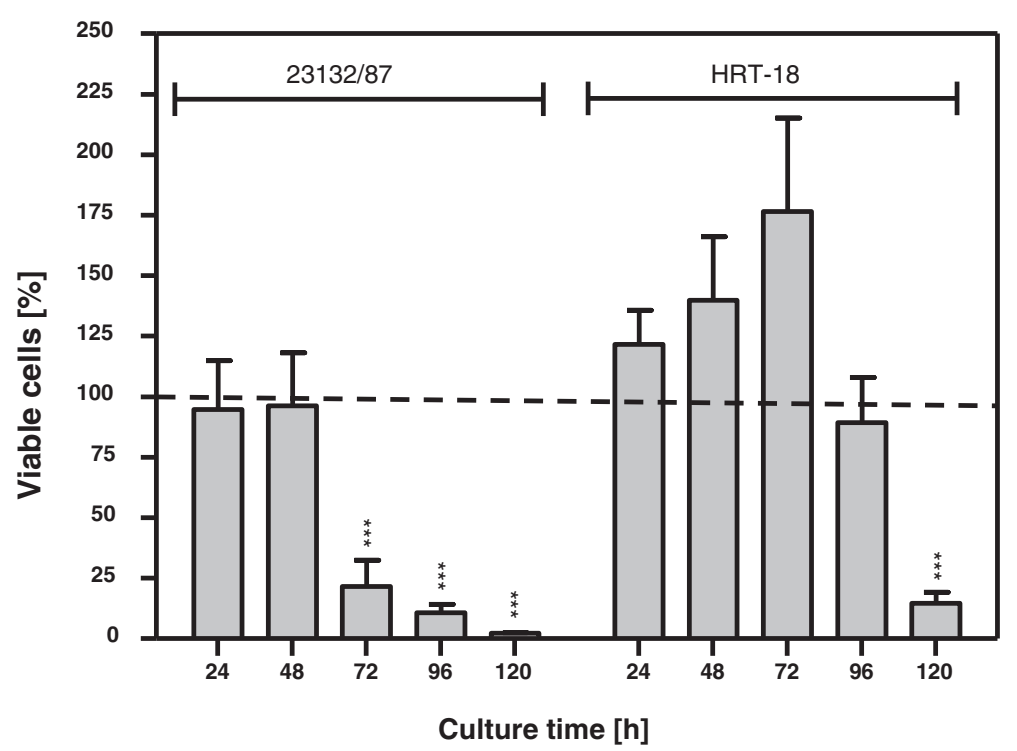

Fig. 3 Viability of HRT-18 and 23132/87 cells continuously cultured with FWGE. Incubation of 23132/87 and HRT-18 cells with 10 mg/ml FWGE was cytotoxic after $72 \mathrm{~h}$ of continuous culture for 23132/87 cells and after $120 \mathrm{~h}$ for HRT-18 cells. Cells were incubated in medium with $10 \%$ ( $\mathrm{v} / \mathrm{v})$ fetal calf serum and cell viability was determined by crystal violet staining at the culture times indicated. The dashed line indicates the relative initial cell count at the start of treatment. For this, the seeded cells were stained with crystal violet directly after their adherence and the absorbance was normalized to $100 \%$. By definition, a cytotoxic effect was a reduction in initial viable cell count >15 \%, a cytostatic effect a change in initial cell count $\pm 15 \%$ and a delayed growth effect an increase in the initial cell count $>15 \%$. Results are shown as mean \pm standard deviation for three independent experiments, each performed in triplicate for each time point. ${ }^{* *} P<0.001$ in comparison to $24 \mathrm{~h}$

from exogenous sources [11], underlining the role of glutathione as a free radical scavenger in cell cultures as described elsewhere [25]. In addition, the thiolic antioxidant $\mathrm{N}$-acetylcysteine and catalase both displayed protective effects and prevented DMBQ/FWGE-induced cell damage (not shown). In contrast to its cytotoxic effect, the cytostatic and growth delay effects of FWGE appear to be independent of oxidative stress and glutathione had no observable effect on cell viability.

A review of the literature shows that intracellular flavoenzymes play an important role in quinone bioactivation [25]. In addition, activation of DMBQ outside the cell with ROS-induced lipid peroxidation is described as a possible mechanism for quinone cytotoxicity [25, 27]. The barrier function of the plasma membrane is lost and DMBQ diffuses through the open plasma membrane into the cytoplasm with intracellular ROS production. With the exception of BxPC3 and ASPC-1 cells, DMBQ showed a need for ascorbic acid in order to induce DMBQ-mediated ROS production. Ascorbic acid acts as electron donor and reduces DMBQ to semiquinone radicals [9]. It can be transported across the plasma membrane into the cell via the sodium-dependent vitamin $C$ transporter or, in its oxidized form, via glucose transporter, including the ubiquitously expressed Glut1 [28]. In contrast to DMBQ, the antiproliferative effect of FWGE was not influenced by ascorbic acid (not shown).
Some of the mechanisms of action for FWGE can be classified as metabolic effects [14]. For example, FWGE prevents glucose uptake into cells and inhibits key enzymes of glycolysis such as hexokinase and lactate dehydrogenase $[17,18]$. Under sufficient oxygenation, normal cells direct glucose predominantly to mitochondrial oxidative phosphorylation to generate ATP, while cancer cells often exhibit nonoxidative glucose utilization, which enhances lactic acid production by lactate dehydrogenase (LDH). The reaction of $\mathrm{LDH}$ leads to the oxidization of $\mathrm{NADH}$ to $\mathrm{NAD}^{+}$, necessary to support glycolytic flux [15]. The exact role and regulation of a hyperactivated glycolytic pathway in cancer cells, termed aerobic glycolysis or the Warburg effect, is still not fully understood. Its major benefit to cancer cells is rapid ATP production and increased supply with anabolic substrates [29]. To determine FWGE-induced alterations in cancer cell metabolism, we measured glucose consumption and generation of lactic acid during cell culture. FWGE impaired glucose consumption of 23132/87 cells and HRT-18 cells caused a low NADH/NAD ${ }^{+}$ratio, an indication of decreased glucose flux through glycolysis. In contrast to 23132/87 cells, FWGE-treated HRT-18 cells formed more lactic acid than would be expected from the low glucose consumption. An alternative pathway for the generation of lactic acid independent of glucose utilization is glutaminolysis. This pathway is 

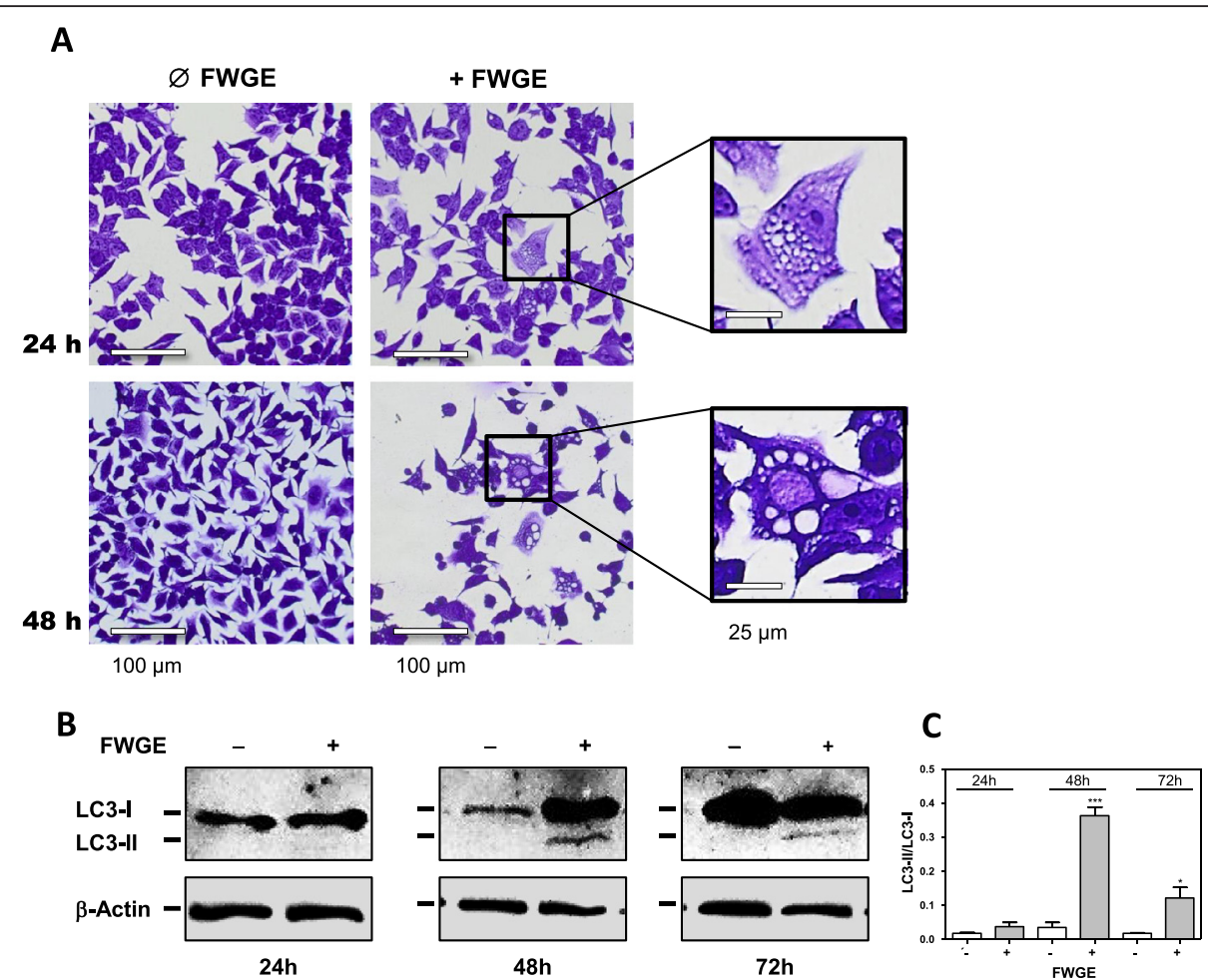

Fig. 4 FWGE-induced autophagic activity in the colon carcinoma cell line HRT-18. FWGE-treated HRT-18 cells showing intracellular vacuoles $24 \mathrm{~h}$ after start of incubation. The vacuoles increased in size with increasing incubation time (a). Presence of endogenous LC3-II in HRT-18 cells with and without FWGE treatment at different incubation times (b). LC3-I (approximately $17 \mathrm{kDa}$ ) is the cytosolic form of LC3, which is converted into the active, membrane-bound form LC3-II (approximately 14-15 kDa) during the autophagy process. $\beta$-actin was used as a loading control (42 kDa). The shift from LC3-I to LC3-II is evident following FWGE treatment. Western blot results are shown for one trial representative of three independent experiments (c). The LC3-II/LC3-I ratio was calculated based on densitometry analysis (ImageJ 1.3.4 s downloaded from the National Institutes of Health $(\mathrm{NIH})$, Bethesda, MD, USA) of LC3-I and LC3-II bands for three independent experiments ( ${ }^{* * *} P<0.001,{ }^{*} P<0.05$ in comparison to FWEG-untreated cells)

involved in the conversion of cytosolic malic acid into pyruvic acid by malic enzymes [30], where excess pyruvic acid is then depleted by LDH. The impact of glutamine on formation of lactic acid independent of glycolysis by FWGE-treated HRT-18 cells was not an object of this study and will be addressed in further studies.

FWGE-treated HRT-18 cells exhibited autophagic activity as demonstrated by the presence of the autophagy marker LC3-II [31]. Autophagy is a self-degradation process which is proposed to have a pro-survival effect for cancer cells under metabolic stress by shifting the energy production from glycolysis towards degradation of unneeded proteins and fatty acids to feed the citric acid cycle for generating ATP [32]. In this context, we found unchanged ATP levels in FWGE-treated HRT-18 cells, indicating that they are able to compensate the impaired glucose utilization during incubation with FWGE and maintain glycolysis-independent ATP production. In addition, HRT-18 cells had prolonged cell survival during continuous culture with FWGE in comparison to 23132/87 cells, which did not exhibit autophagy (Fig. 3). Taken together, the antiproliferative properties of FWGE display a complex interaction with cancer cell metabolism.

\section{Conclusions}

The antiproliferative properties of FWGE are complex and differ in some respects from those of the DMBQ compound. This may explain why there is to date no evidence of toxic side effects from FWGE in clinical trials in contrast to clinically applied quinone compounds. In addition to its cytotoxic effect, FWGE also has cytostatic and growth delay effects at a concentration of $10 \mathrm{mg} / \mathrm{ml}$ after $24 \mathrm{~h}$ of incubation, while $24 \mu \mathrm{mol} / \mathrm{l}$ of the DMBQ compound (equal to the DMBQ concentration in FWGE) was uniformly cytotoxic for all cancer cell lines we tested. The oxidative cell damage potential of activated DMBQ was confirmed by aberrant intracellular DCF fluorescence, indicating increased levels of intracellular ROS. A marked increase of ROS was also found to underlie the cytotoxic effect of FWGE. Moderate levels of intracellular ROS were found to underlie the cytostatic and growth delay effects of FWGE which were linked to impaired glucose utilization and induction of autophagy, a previously unknown mechanism of FWGE for targeting cancer cell metabolism. 


\section{Additional files}

Additional file 1: Figure S1. Antiproliferative properties of FWGE and DMBQ on cancer cells. $10 \mathrm{mg} / \mathrm{ml}$ FWGE exhibited cytotoxic (a) and cytostatic (b) effects after $24 \mathrm{~h}$ of culture. The growth delay effect in HRT18 cells is shown in Fig. 1. Representative figures of crystal violet stained viable cancer cells treated with FWGE and DMBQ after $24 \mathrm{~h}$ of culture (c). DMBQ displayed a strong cytotoxic effect in all cancer cell lines. The dashed line indicates the relative initial cell count at the start of treatment. For this, the seeded cells were stained with crystal violet directly after their adherence and the absorbance was normalized to $100 \%$. By definition, a cytotoxic effect was a reduction in initial viable cell count $>15 \%$, a cytostatic effect a change in initial cell count $\pm 15 \%$ and a delayed growth effect an increase in the initial cell count $>15 \%$. Ascorbic acid $(2.4 \mathrm{mmol} / \mathrm{l})$ was used to activate DMBQ [16] and had no influence on cell viability or the effect of FWGE (not shown). Results are shown as mean \pm standard error of mean (S.E.M.) and representative for at least three independent experiments performed in triplicate. Magnification: 80x. ${ }^{*} P<0.05$, ${ }^{*} P<0.01$, ${ }^{* * *} P<0.001$ in comparison to untreated control cells. (PDF $216 \mathrm{~kb}$ )

Additional file 2: Figure S2. The protective effect of exogenous glutathione on the viability of cancer cells treated with FWGE/DMBQ. The protective effects of exogenous glutathione (GSH) protected against DMBQ and FWGE-induced cytotoxicity in BxPC-3, 23132/87, and HRT-18 cells. GSH did not influence FWGE-induced cytostatic and growth delay effects. Cancer cells were treated with FWGE $(10 \mathrm{mg} / \mathrm{ml})$ or DMBQ (24 $\mu \mathrm{mol} / \mathrm{l}$ ) with (+) and without (-) GSH for $24 \mathrm{~h}$. The GSH concentration (3.6 mmol/l) used was optimal as determined in previous studies. The dashed line indicates the relative initial cell count at the start of treatment. For this, the seeded cells were stained with crystal violet directly after their adherence and the absorbance was normalized to $100 \%$. Results present the mean $( \pm$ S.E.M.) of three independent experiments, each performed in triplicate. Cancer cells were cultured in RPMI 1640 medium with $10 \%$ (v/v) fetal calf serum (FCS). ${ }^{* *} \mathrm{P}<0.01$ in comparison to untreated control cells, n.s. $=$ not significant. (PDF $15 \mathrm{~kb}$ )

Additional file 3: Figure S3. Demonstration of the presence of DTdiaphorase in cancer cells and fibroblasts. ASPC-1 and BXPC-3 cells exhibited a complete loss of the enzyme DT-diaphorase (NAD(P)H:quinone oxidoreductase, NQO1), which protects cells particularly against benzoquinone-induced oxidative stress and can explain the sensitivity of BxPC-3 and ASPC-1 cells (not shown) to incubation with FWGE and DMBQ. Whole cell extracts of ASPC-1, BXPC-3, 23132/87, HRT-18 cells and normal human dermal fibroblasts (NHDF from PromoCell, Germany) were separated on SDS-PAGE and probed with rabbit anti-DTdiaphorase antibody, which detects a protein band of $28 \mathrm{kDa}$. A monoclonal mouse anti- $\beta$-actin primary antibody was used as loading control (42 kDa). (PDF $26 \mathrm{~kb}$ )

Additional file 4: Figure S4. Cell cycle analysis of FWGE-treated and untreated cells. The cell cycle was analyzed $24 \mathrm{~h}$ after start of incubation with FWGE $(10 \mathrm{mg} / \mathrm{ml})$. Isolated nuclei were stained with propidium iodide (PI) and then subjected to flow cytometry analysis for their DNA content. FACS profiles for 23132/87 cells (a) and HRT-18 cells (b). Results are shown as mean \pm S.E.M. from three different experiments. The bar graph shows the percentages of cells in G1, S, and G2/M. ${ }^{*} P<0.05$, n.S., not significant. (PDF $121 \mathrm{~kb}$ )

\section{Abbreviations}

ATP, adenosine triphosphate; CV, crystal violet; DCFH-DA, 2',7'-dichlorofluorescin diacetate; DMBQ, 2,6-dimethoxy-1,4-benzoquinone; FWGE, fermented wheat germ extract; $I_{50}$, half maximal inhibitory concentration; NAD, nicotinamide adenine dinucleotide; PBS, phosphate buffered saline; RFU, relative fluorescence units; $\mathrm{ROS}$, reactive oxygen species.

\section{Acknowledgements}

The authors are grateful to Sabine Gahn, Manuela Hofmann, Michaela Kapp, Monika Koospal, and Bettina Mühling for their skillful assistance with the experiments.

\section{Funding}

The study was supported by funds from the Interdisciplinary Centre for Clinical Research (IZKF) of the University of Würzburg (B-186 to AW, and D-150 to CO). The publication was funded by the University of Würzburg through the funding program »Open Access Publishing«.

\section{Availability of data and materials}

The datasets supporting the conclusions of this article are included within the article and its additional files.

\section{Authors' contributions}

$\mathrm{CO}, \mathrm{TH}, \mathrm{KE}, \mathrm{FK}, \mathrm{CJ}, \mathrm{AW}$, and UK designed the study, performed the experiments, participated in data collection, analysed and interpreted the results, and drafted the manuscript; $\mathrm{CO}, \mathrm{UK}$, AW contributed reagents, materials, and analytic tools; CTG, AW, UK checked the article for intellectual content and participated in editorial support. All authors read and approved the final manuscript.

\section{Competing interests}

The authors declare that they have no competing interests. This publication reflects only the authors' views.

\section{Consent for publication}

Not applicable.

\section{Ethics approval and consent to participate}

Not applicable.

\section{Author details}

${ }^{1}$ Experimental Surgery, Department of General, Visceral, Vascular, and Pediatric Surgery, University Hospital of Würzburg, Oberdürrbacher Str. 6, D-97080 Würzburg, Germany. ${ }^{2}$ Present Address: Spital Bülach, Medizinische Klinik, Spitalstrasse 24, 8180 Bülach, Germany. ${ }^{3}$ Present Address: Missionsärztliche Klinik, Fachabteilung Urologie, Salvatorstraße 7, 97074 Würzburg, Germany. ${ }^{4}$ Present Address: Klinik für Allgemein-, Viszeral-, Gefäßund Thoraxchirurgie, Krankenhaus Leopoldina der Stadt Schweinfurt, Gustav-Adolf-Straße 8, 97422 Schweinfurt, Germany. ${ }^{5}$ Department of General, Visceral, Vascular and Pediatric Surgery, University Hospital of Würzburg, Oberdürrbacher Str. 6, D-97080 Würzburg, Germany. ${ }^{6}$ Department of Biochemistry and Molecular Biology, Theodor-Boveri-Institute, Biocenter, University of Würzburg, D-97070 Würzburg, Germany. ${ }^{7}$ Department of Obstetrics and Gynaecology, University Hospital of Würzburg, Josef-Schneider-Str. 4, D-97080 Würzburg, Germany.

Received: 3 September 2015 Accepted: 25 May 2016

Published online: 01 June 2016

References

1. Heimbach JT, Sebestyen G, Semjen G, Kennepohl E. Safety studies regarding a standardized extract of fermented wheat germ. Int J Toxicol. 2007:26(3):253-9.

2. Hidvégi M, Rásó E, Tömösközi-Farkas R, Paku S, Lapis K, Szende B. Effect of Avemar and Avemar + Vitamin C on tumor growth and metastasis in experimental animals. Anticancer Res. 1998;18:2353-8.

3. Hidvégi M, Rásó E, Tömösközi-Farkas R, Szende B, Paku S, Prónai L, et al. MSC, a new benzoquinone-containing natural product with antimetastatic effect. Cancer Biother Radiopharm. 1999;14(4):277-89.

4. Jakab F, Shoenfeld Y, Balogh Á, Nichelatti A, Kahán Z, Lapis K, et al. A medical nutriment has supportive value in the treatment of colorectal cancer. Br J Cancer. 2003:89:465-9.

5. Demidov LV, Manziuk LV, Kharkevitch GY, Pirogova NA, Artamonova EV. Adjuvant fermented wheat germ extract (Avemar) nutraceutical improves survival of high risk skin melanoma patients: a randomized pilot phase II clinical study with a 7-year follow-up. Cancer Biother Radiopharm. 2008;23(4):477-82

6. O'Brien PJ. Molecular mechanisms of quinone cytotoxicity. Chem Biol Interact. 1991:80:1-41.

7. Piccart-Gebhart MJ. Anthracyclines and the tailoring of treatment for early breast cancer. N Engl J Med. 2006:354(20):2177-9.

8. Bachur NR, Gordon SL, Gee MV. A general mechanism of microsomal activation of quinone anticancer agents to free radical. Cancer Res. 1978;38:1745-50. 
9. Pethig R, Gascoyne PRC, McLaughlin JA, Szent-Györgyi A. Ascorbatequinone interactions: electrochemical, free radical and cytotoxic properties. Proc Natl Acad Sci U S A. 1983;80:129-32.

10. Winterbourn CC. Reconciling the chemistry and biology of reactive oxygen species. Nat Chem Biol. 2008;4(5):278-86.

11. Circu ML, Aw TY. Glutathione and modulation of cell apoptosis. Biochim Biophys Acta. 2012;1823(10):1767-77.

12. Liou GY, Storz P. Reactive oxygen species in cancer. Free Radic Res. 2010:44(5):479-96

13. Lind $\mathrm{C}$, Hochstein P, Ernster L. DT-diaphorase as a quinone reductase: a cellular control device against semiquinone and superoxide radical formation. Arch Biochem Biophys. 1982;216(1):178-85.

14. Illmer C, Madlener S, Horvath Z, Saiko P, Losert A, Herbacek I, et al. Immunologic and biochemical effects of the fermented wheat germ extract Avemar. Exp Biol Med. 2005:230:144-9.

15. Gatenby RA, Gillies RJ. Why do cancers have high aerobic glycolysis? Nat Rev Cancer. 2004:4(11):891-9.

16. Verrax J, Vanbever S, Stockis J, Taper H, Calderon PB. Role of glycolysis inhibition and poly(ADP-ribose) polymerase activation in necrotic-like cell death caused by ascorbate/menadione-induced oxidative stress in K562 human chronic myelogenous leukemic cells. Int J Cancer. 2007;120(6):1192-7.

17. Boros LG, Lapis K, Szende B, Tömösközi-Farkas R, Balogh A, Boren J, et al. Wheat germ extract decreases glucose uptake and RNA ribose formation but increases fatty acid synthesis in MIA pancreatic adenocarcinoma cells. Pancreas. 2001;23(2):141-7.

18. Comin-Anduix B, Boros LG, Marin S, Boren J, Callol-Massot C, Centelles $\mathrm{JJ}$, et al. Fermented wheat germ extract inhibits glycolysis/pentose cycle enzymes and induces apoptosis through poly(ADP-ribose) polymerase activation in Jurkat T-cell leukemia tumor cells. J Biol Chem. 2002;277(48):46408-14.

19. Saiko P, Ozsvar-Kozma M, Madlener S, Bernhaus A, Lackner A, Grusch M, et al. Avemar, a nontoxic fermented wheat germ extract, induces apoptosis and inhibits ribonucleotide reductase in human $\mathrm{HL}-60$ promyelocytic leukemia cells. Cancer Lett. 2007:250:323-8.

20. Klingelhoeffer C, Kämmerer U, Koospal M, Mühling B, Schneider S, Kapp M et al. Natural resistance to ascorbic acid induced oxidative stress is mainly mediated by catalase activity in human cancer cells and catalase-silencing sensitizes to oxidative stress. BMC Complementary and Altern Med. 2012;12:61. doi:10.1186/1472-6882-12-61.

21. Huber W, Koella JC. A comparison of three methods of estimating $E C_{50}$ in studies of drug resistance of malaria parasites. Acta Trop. 1993;55(4):257-61.

22. Wiegering A, Korb D, Thalheimer A, Kämmerer U, Allmannritter J, Matthes $\mathrm{N}$, et al. E7080, a multitargeted tyrosine kinase inhibitor, demonstrates antitumor activities against colorectal cancer xenografts. Neoplasia. 2014;16(11):972-81.

23. Kämmerer U, Gires O, Pfetzer N, Wiegering A, Klement RJ, Otto C. TKTL1 expression in human malign and benign cell lines. BMC Cancer. 2015;15:2. doi:10.1186/1471-2407-15-2.

24. Powis G. Metabolism and reactions of quinoid anticancer agents. Pharmacol Ther. 1987;35(1-2):57-162.

25. Butler J, Hoey BM. Are reduced quinones necessarily involved in the antitumour activity of quinone drugs? Br J Cancer Suppl. 1987;8:53-9.

26. Kalyanaraman B, Darley-Usmar V, Davies KJ, Dennery PA, Forman HJ, Grisham MB, et al. Measuring reactive oxygen and nitrogen species with fluorescent probes: challenges and limitations. Free Radic Bio Med. 2012;52(1):1-6.

27. Triton TR, Yee $\mathrm{G}$. The anticancer agent adriamycin can be actively cytotoxic without entering cells. Science. 1982;217(4556):248-50.

28. Wilson JX. Regulation of vitamin C transport. Annu Rev Nutr. 2005;25:105-25.

29. Cairns RA, Harris IS, Mak TW. Regulation of cancer cell metabolism. Nat Rev Cancer. 2011;11(2):85-95.

30. Wise DR, DeBerardinis RJ, Mancuso A, Sayed N, Zhang XY, Pfeiffer HK, et al. Myc regulates a transcriptional program that stimulates mitochondrial glutaminolysis and leads to glutamine addiction. Proc Natl Acad Sci U S A. 2008;105(48):18782-7.

31. Tanida I, Minematsu-lkeguchi N, Ueno T, Kominami E. Lysosomal turnover, but not a cellular level, of endogenous LC3 is a marker for autophagy. Autophagy. 2005;1(2):84-91.

32. Pérez-Mancera PA, Young AR, Narita M. Inside and out: the activities of senescence in cancer. Nat Rev Cancer. 2014:14(8):547-58.
33. Cailleau R, Young R, Olivé M, Reeves Jr WJ. Breast tumor cell lines from pleural effusions. J Natl Cancer Inst. 1974;53(3):661-74.

34. Deer EL, González-Hernández J, Coursen JD, Shea JE, Ngatia J, Scaife CL, et al. Phenotype and genotype of pancreatic cancer cell lines. Pancreas. 2010;39(4):425-35

35. Vollmers HP, Stulle K, Dämmrich J, Pfaff M, Papadopoulos T, Betz C, Saal K, Müller-Hermelink HK. Characterization of four new gastric cancer cell lines. Virchows Arch B Cell Pathol Incl Mol Pathol. 1993;63(6):335-43.

36. Fogh J, Fogh JM, Orfeo T. One hundred and twenty-seven cultured human tumor cell lines producing tumors in nude mice. J Natl Cancer Inst. 1977:59(1):221-6.

37. Holliday DL, Speirs V. Choosing the right cell line for breast cancer research. Breast Cancer Res. 2011;13(4):215. doi:10.1186/bcr2889.

38. Tompkins WA, Watrach AM, Schmale JD, Schultz RM, Harris JA. Cultural and antigenic properties of newly established cell strains derived from adenocarcinomas of the human colon and rectum. J Natl Cancer Inst. 1974;52:1101-10.

\section{Submit your next manuscript to BioMed Central and we will help you at every step:}

- We accept pre-submission inquiries

- Our selector tool helps you to find the most relevant journal

- We provide round the clock customer support

- Convenient online submission

- Thorough peer review

- Inclusion in PubMed and all major indexing services

- Maximum visibility for your research

Submit your manuscript at www.biomedcentral.com/submit
C Biomed Central 